Hanna Ratuszna*

\section{Kobiety i sztuka słowa}

DOI: http://dx.doi.org/10.12775/LC.2017.046

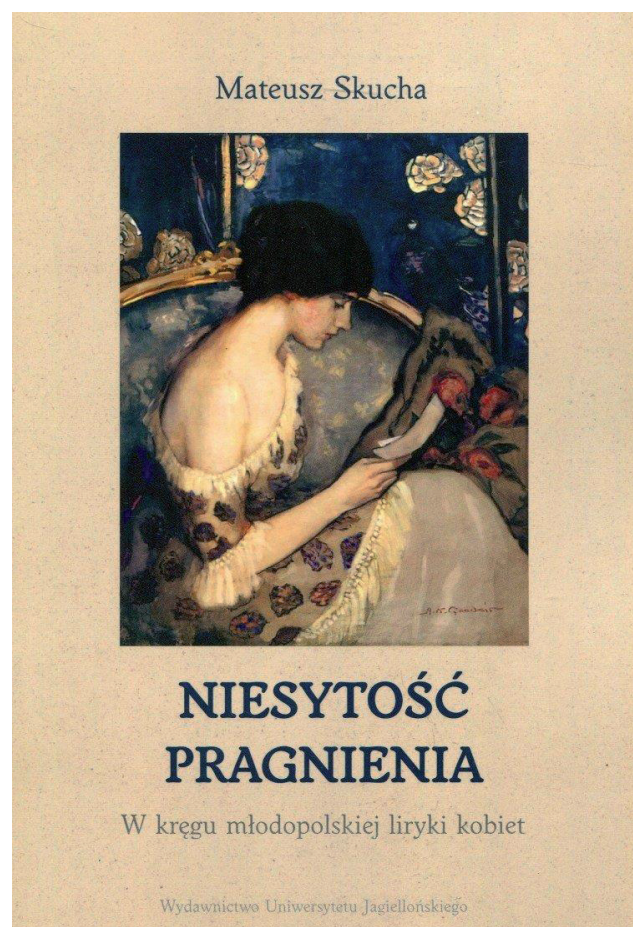

Kobieta jest światłem, spojrzeniem, zaproszeniem do szczęścia, niekiedy słowem; nade wszystko jednak ogólną harmonią, nie tylko dzięki swej postawie i ruchom ciała, ale także dzięki muślinom, gazom, wielkim migocącym obłokom spowijających ją tkanin, które stanowią niejako atrybuty i piedestał jej boskości; dzięki metalom i minerałom ślizgającym się wokół ramion i szyi, dorzucającym iskier do ognia

* Dr hab., prof. UMK w Zakładzie Literatury Młodej Polski i Dwudziestolecia Międzywojennego, w Instytucie Literatury Polskiej Uniwersytetu Mikołaja Kopernika w Toruniu. E-mail: alef2@wp.pl. jej spojrzeń lub szepczącym jej łagodnie do ucha ${ }^{1}$.

e słowa Baudelaire'a odzwierciedlają fascynacje fenomenem kobiecości, towarzyszące artyście. Kobieta jest muzą i przekleństwem mężczyzny, zwycięstwem i klęską... indywidualizmu. Baudelaire trafnie opisał owe ambiwalencje i jako jeden z pierwszych powiązał je ze sztuką symboliczną:

Otchłani mego serca, ciebie trzeba, ciebie Lady Makbet, kobieto z potęgą zbrodniczą, Śnie Eschyla, zrodzony na północnej

Lub ciebie Nocy, córo Michała Anioła ${ }^{2}$

$$
\text { glebie, }
$$

Literatura schyłku XIX wieku „odzwierciedlała potęgę uczuć", stanowiła triumf wyobraźni, była „królestwem ducha” - jak określił ją autor Kwiatów zła. Podobnie jak Poe, Baudelaire ujawnił w swej twórczości demony, biesy ludzkiej duszy, kobieta zaś stała się symbolem sztuki. Idea ta zyskała interesującą realizację w twórczości innych symbolistów, którzy w poezji (Leconte de Lisle) czy malarstwie (Kaufmann, Klimt, Moreau) prezentowali różnorodność „przestrzeni kobiecości”. Kobiety artystki jedynie pośrednio stały się wyrazicielkami wspomnianej idei, ich miejsce na Parnasie nie było aż tak oczywiste. Wzorce kulturowe, style wychowania, oczekiwania społeczne stanowily istotne przeszkody $\mathrm{w}$ realizacji artystycznych aspiracji. Twórczość kobiet była zatem traktowana marginalnie, choć ceniono ich wpływ na sztukę.

\footnotetext{
1 Ch. Baudelaire, Kobieta, [w:] idem, O sztuce. Szkice krytyczne, wybrała i oprac. J. Guze, wstęp J. Starzyński, Wrocław-Warszawa-Kraków 1961, s. 222.

2 Idem, Ideat, [w:] Symboliścifrancuscy. Od Baudelaire'a do Valery'ego, wstęp i wybór M. Jastrun, Wrocław-Warszawa-Kraków 1965, s. 23.
} 
Książka Mateusza Skuchy pt. Niesytość pragnienia stanowi próbę opisu fenomenu kobiecości, „młodopolskiej twórczości kobiet" (określenie to wymaga uzasadnienia, które czytelnik odnajduje w podrozdziale pt. Poetki Młodej Polski - od fin de siècléu do XXI wieku). W dyskursach o kobietach dawnym, naznaczonym emancypacyjnym kodem oraz ponowoczesnym, feministycznym - ujawnione zostaje źródło konfliktów podważających u schyłku XIX wieku utrwalony przez romantyków portret kobiety - muzy, genialnej wieszczki. W przedstawionych szkicach, portretach najbardziej znanych artystek przełomu wieków, przeważa wizerunek skrywanego talentu, tłumionych emocji, zdegradowanych uczuć. Portret kobiety przełomu wieków, pokryty patyną, inspiruje do rozpoznawania współczesnych lęków, twórczych niepokojów. Autor tak komentuje owe inspiracje:

Młodopolska poezja kobieca jest dla mnie lustrem, w którym przegląda się kobieta przełomu XIX i XX wieku. Odbija się w nim jej skomplikowana tożsamość, uwikłana w różne dyskursy - Genderowe, poetyckie, narodowe, macierzyńskie, kulturowe, historyczne i rasowe. Ta kobieta pełna wątpliwości, obaw i lęków, lecz także nadziei i wiary w siebie oraz własne możliwości. Ale w lustrze tym przegląda się także mężczyzna ... ${ }^{3}$

Nie przypadkiem Mateusz Skucha rozpoczyna swoją narrację od analizy twórczości Marii Komornickiej, enfant terrible literatury modernistycznej, ikony współczesnych dyskursów feministycznych („biografizmów”). Komornicka, jako jedna z pierwszych artystek, po ważnym debiucie, zrzekła się kobiecości, zaprzeczyła płciowości; konflikt ról stał się przyczyną kryzysu,

\footnotetext{
3 M. Skucha, Niesytość pragnienia. W kręgu młodopolskiej liryki kobiet, Kraków 2016, s. 12.
}

jednym z powodów jej zniknięcia ze sceny literackiej.

Należy pamiętać, że twórczość poetycka Komornickiej, która zyskuje w rozprawie Mateusza Skuchy interesujące interpretacje, jest jednak zaledwie dopełnieniem twórczości krytycznej, o której niewiele do tej pory napisano (por. Maria PodrazaKwiatkowska ${ }^{4}$, Anna Wydrycka ${ }^{5}$ ). Tropione w poezji postawy ja lirycznego pozwalają tworzyć uogólniające wnioski o transgresywności, samotności ja, które porzuca „kobiecy status”.

W twórczości Komornickiej można wyróżnić trzy istotne okresy: debiutu, kryzysu osobowości i choroby. Każdy z nich kształtuje inne postawy, w każdym dominuje inna „strategia” ja wobec płci, fenomenu kobiecości. Okres debiutu jest czasem, w którym poetka ukrywa swoją kobiecość. Męski pseudonim jest nie tylko maską, pod którą znika niewieście oblicze, to poniekąd wzorzec myślenia, styl ekspresji, kod dyskursu, który Autor określa jako „sposób zaistnienia $\mathrm{w}$ przestrzeni społeczno-kulturalnego dyskursu"':

Wiąże się to z hierarchią społeczną, według której mężczyźni jako działające podmioty rządzą światem i kobietami jako biernymi obiektami męskiej władzy i męskiego pożądania. I znów (tak jak w przypadku stroju), aby stać się człowiekiem w ogóle, podmiotem aktywnie partycypującym $\mathrm{w}$ dyskursie społeczno-kulturowym, należy zakwestionować $\mathrm{w}$ sobie kobietę 7 .

Zakwestionowanie w sobie kobiety, jak słusznie dowodzi Autor, dokonuje się także

\footnotetext{
4 M. Podraza-Kwiatkowska, Tragiczna wolność. O Marii Komornickiej, [w:] eadem, Somnabulicy - dekadenci - herosi. Studia i eseje o literaturze Mtodej Polski, Kraków 2001.

5 A. Wydrycka, Zapomniane głosy. Krytyka literacka kobiet 1894-1918, Białystok 2006.

6 M. Skucha, op. cit., s. 31.

7 Ibidem.
} 
w tekście. Czy możliwy jest apłciowy, bezcielesny podmiot? Pytanie to powraca w kolejnych rozdziałach nieustannie.

Ciało jest nie tylko więzieniem duszy, czy jak je określił Bolesław Leśmian - „purpurą jagód przeciążonym dzbanem”, jest przede wszystkim ciałem pożądliwym i cierpiącym, znojnym, staje się zatem źródłem sensów. W dyskursie ponowoczesności, do którego odwołuje się Skucha, ujawnia także symboliczne znaczenie. W twórczości Marii Komornickiej zarysowuje się w wyraźny sposób konflikt między ciałem a duszą, porządkiem cielesnym i duchowym. Podmiot liryczny staje wówczas „na rozdrożu”, przed wyborem jednej z dróg. Ta perspektywa „albo-albo" pozwala interpretować twórczość autorki Biesów w duchu preegzystencjalnym. Podobnie jak w pismach Kierkegaarda (np. Albo-albo), podmiot liryczny wierszy Komornickiej pokonuje stadia na drodze życia, marzy o religijności, której nie pojmuje jednak w duchu pism duńskiego filozofa. Ostatnie stadium ma przynieść wolność, o jakiej podmiot liryczny zawsze marzył (por. Hymny nadziei). Autor książki Niesytość pragnienia skupia swoją uwagę przede wszystkim na drugim okresie twórczości, zadaje także pytanie o możliwość zaistnienia tekstu kobiecego, o koncepcję écriture féminine.

W wierszach pochodzących z Xięgi poezji idyllicznej podmiot liryczny nie jest bezcielesny, ciało staje się krwawiącą raną, poddawane medycznym zabiegom potęguje cierpienie (por. wiersz Po operacji). Cierpiącemu ciału zawsze „towarzyszy” równie udręczona dusza - anima, animula.

W dorobku Komornickiej ważną rolę pełni także twórczość o charakterze autotematycznym. Lektura książki Mateusza Skuchy pozwala zrozumieć wagę tego te-

8 B. Leśmian, Godzina zielona, [w:] idem, Sad rozstajny, Warszawa 1912. matu w pisarstwie kobiet. Rozdział pt. Tekstualna androgynia prezentuje niuanse „modernistycznego kobiecego autotematyzmu”. Akt twórczy, twórcza postawa, proces tworzenia - stają się kluczowe w poezji, która jest opisywaniem świata. Komornicka wyraźnie akcentuje różnice między aktem twórczym a możliwościami jednostki, podmiot liryczny jej wierszy pozostaje bierny, samotny, niekiedy zrezygnowany, nawet bunt jest wówczas straceńczym gestem, podszytym rozpaczą (por. Bunt aniota), nie porzuca jednak raz obranej drogi - samodoskonalenia, samopoznania. Żałować należy, że w rozdziale poświęconym Komornickiej nie znalazły się uwagi o publicystyce autorki Przejściowych. W artykułach pisanych w pierwszym okresie twórczości (Forpoczty) pojawia się męska kreacja podmiotu, który czasem wypowiada się w imieniu pokolenia.

Podobna strategia analizy postaw i ról kobiecego podmiotu lirycznego towarzyszy prezentacji twórczości innej autorki, Zofii Trzeszczkowskiej. Mateusz Skucha odnajduje w jej poezji obecność „męskiego artefaktu" - jej gry z czytelnikami (ukrywanie się pod męskim pseudonimem, pisanie z perspektywy przeżywającego rzeczywistość mężczyzny) traktuje jednak nie tylko jako próbę wpisania się $\mathrm{w}$ obowiązujący kod społeczno-kulturowy (jak w przypadku Komornickiej), lecz jako wyraz postawy wobec ciała naznaczonego seksualnie, która ujawnia się w przyjętych strategiach lektury (lektury wrażliwej na płeć, wrażliwej na seksualność i niewrażliwej na płeć). Autor sięga w szkicu poświęconym Trzeszczkowskiej po teorię queer. Wybór ten wynika z przyjętych założeń - prowadzona przezeń analiza dotyczy postaw podmiotu lirycznego wiersza pt. Posag, a nie autorki, która ukrywa swoją płeć i tożsamość pod męskim pseudonimem.

Problem takiego właśnie ujęcia zagadnienia wydaje się ciekawy, choć nie całkiem 
przekonujący. Autor uruchamia tropy poststrukturalistycznych dyskursów teoretycznych, które pozwalają odczytać tekst na nowo. W świetle przeprowadzonych analiz utwór Posag Zofii Trzeszczkowskiej prezentuje bogactwo maskowanej tożsamości:

Posąg jest względnie reprezentatywnym przykładem modernistycznej literatury homoseksualnej - określanej czasem jako literatura homoseksualna przedemancypacyjna. Jest to taki rodzaj wypowiedzi literackiej, w której homoseksualna tożsamość narratora (lub podmiotu lirycznego) jest ukrywana w tekście (mowa m.in. o „niewypowiadalnym pożądaniu”) i ujawnia się dopiero w trakcie specyficznej strategii lekturowej (mającej swe źródło w studiach gejowskich) ${ }^{9}$.

Powołując się na teorie Irigaray i Cixous, Autor uzasadnia ten fakt niemożliwością wyrażenia kobiecego jouissance. Jedynie męska tożsamość pozwala na pełną wypowiedź ${ }^{10}$. Stanowisko to pojawia się jako kolejna możliwość odczytania wiersza: versus płci, seksualności wyrażonego $\mathrm{w}$ utworze podmiotu, pozwala uruchomić nową lekturę. $\mathrm{W}$ ten sposób wyznaczona zostaje jeszcze jedna „droga interpretacji” (trzeba jednak przyznać, że dość słabo umotywowana w rozważaniach Autora) - prowadzona w duchu queer criticism, dla której najważniejsze wydają się napięcia, zależności „między tożsamością podmiotu, różnicą płciową i seksualną a pożądaniem"11.

Mateusz Skucha nie wybiera jednej z zaproponowanych interpretacji, jego zdaniem przedstawione symulacje lekturowe uzupełniają się. Wątek biograficzny i kontekst kulturowy (sytuacja kobiet piszących, emancypantek), pobrzmiewające $\mathrm{w}$ tle prowadzonych analiz, dopełniają obraz nie-

\footnotetext{
M. Skucha, op. cit., s. 64.

10 Ibidem, s. 66.

11 Ibidem.
}

pokojów, wyraźnego kryzysu tożsamości, który przyjął niezwykłą formę w utworach polskich poetek przełomu XIX i XX wieku.

Analiza twórczości kolejnych artystek Maryli Wolskiej, Bronisławy Ostrowskiej i Marceliny Kuligowskiej potwierdza tę tezę. Ja liryczne odzwierciedla nie tylko indywidualne problemy tożsamościowe, lecz także niepokoje pokoleniowe: problemy „poetyckiej świadomości emancypacyjnej i niemożności zaistnienia kobiecego podmiotu lirycznego"12.

W rozdziale pt. Ostatnia Sybilla. Poetyckie kreacje Maryli Wolskiej najtrudniej uruchomić trzy ścieżki lektury opisane poprzednio. Wolska jest bowiem artystką, która sięga po literacką tradycję romantyczną, „snuje przędzę poezji”, dyskursywizuje akt twórczy. Strategie podmiotu lirycznego uwzględniają odbiorcę, w twórczości Wolskiej pobrzmiewa głos pokolenia: „My tyle tylko jesteśmy warci, i ile przez nas echa tych rejestrów wysokich zadźwięczą"13.

Podobny ton odnaleźć można w artykułach Marii Komornickiej, która wypowiada się w imieniu pokolenia: „My późno urodzeni przestaliśmy wierzyć w prawdę"14, prezentuje także swoje poglądy na temat miłości (por. Miłość). Jest wówczas wierną uczennicą Fryderyka Nietzschego, który jak powszechnie wiadomo - głosił pochwałę cielesności. Dowartościowanie ciała, specyficzna koncepcja witalizmu stały się ważnymi punktami odniesienia $\mathrm{w}$ teoriach poststrukturalistycznych. Warto pamiętać o tym wątku.

Twórczość Maryli Wolskiej została określona przez krytyków, badaczy (Sierotwiński, Zabawa, Pekaniec) jako ko-

12 Ibidem, s. 87.

13 M. Wolska, My artyści, „Krytyka” 1904, t. 1, R. VI, s. 48-52. Cyt. za M. Skucha, op. cit., s. 96.

14 M. Komornicka, Przejściowi, [w:] Programy i dyskusje literackie epoki Młodej Polski, red. M. Podraza-Kwiatkowska, Kraków 2001. 
bieca. Co oznacza to określenie w dobie współczesnych ustaleń, krytyki feministycznej? Mateusz Skucha dowodzi, że poetka unika w swoich wczesnych lirykach i wypowiedziach publicystycznych cielesnych metafor, rzadko konstruuje kobiecy podmiot liryczny: „Tam, gdzie Wolska świadomie dyskursywizuje kwestie słowa i mówienia, ciało nie odgrywa żadnej roli. Jednakże tam, gdzie pojawiają się metafory milczenia, ujawnia się też ciało. Nawet jeśli poetka nie chce demonstrować płci i cielesności, czyni to. Ale dyskretnie"15.

Nie uda się zatem uciec od ciała, ujawnia się ono nawet w milczeniu. Oczywiście w tak bogatej twórczości można odnaleźć także wyjątki od dostrzeżonej przez Autora zasady, np. w wierszu pt. Jak ta wilga. Zmianę strategii w prezentacji podmiotu lirycznego przynosi jednak tom z roku 1905 pt. Z ogni kupalnych, w którym poetka prezentuje postać kobiety kapłanki - wieszczki. Właśnie rola wieszczki - jak podkreśla Autor szki$\mathrm{cu}$ - jest dla tej twórczości kluczowa, dzięki temu możliwe staje się mówienie o sobie i świecie z perspektywy własnej płci.

Wolska ukrywała swą tożsamość pod męskim pseudonimem (przykładem może być opublikowany w 1910 roku tom pt. Dziewczęta, sygnowany pseudonimem Iwo Płomieńczyk), pozostawała jednak w kręgu kobiecych tematów, takich jak dorastanie (moment przeobrażenia dziewczyny dziecka w kobietę, np. tom opowiadań pt. Dziewczęta), miłość, małżeństwo, kobieca dusza (por. tom pt. Dzbanek malin). Postawa wieszczki czy kapłanki (interesująco przedstawiona w dramacie pt. Swanta) z pewnością wpłynęła znacząco na utrwalenie podmiotu kobiecego w poezji Maryli Wolskiej. Czy jednak na tym właśnie ma polegać twórczość kobieca? Marcin Skucha nie odpowiada na to pytanie wprost. Zagadnienie

\footnotetext{
15 M. Skucha, op. cit., s. 100.
}

kobiecej twórczości wymaga analizy jeszcze innych niż wymienione przez Autora przykładów artystycznych działań. Stosowana przez niego optyka wyznaczona przez tzw. case studies budzi pewien niedosyt.

W tomie, poświęconym wyłącznie poezji, zabrakło kilku ważnych, jak sądzę, autorek - takich jak Ewa Łuskina, Jadwiga Łuszczewska, Wanda Markowska czy Maryla Czerkawska. We Wstępie do tomu Mateusz Skucha przekonująco uzasadnia swój wybór, warto jednak zastanowić się nad rozwinięciem i uzupełnieniem przedstawionych $\mathrm{w}$ tomie Niesytość pragnienia tez. $\mathrm{Z}$ przeprowadzonych analiz wynika bowiem, że problematyczny dla twórczości całej epoki, zapoczątkowany w niej kryzys podmiotu, który w dwudziestowiecznej sztuce przyjął bardzo istotne „rozmiary”, w twórczości poetek rozwijał się w dość specyficzny sposób: dotyczył nie tylko podmiotowych męskich kreacji, ujawnianych w nowoczesnych strategiach lekturowych kontekstach kobiecości utraconej, płci odrzuconej - lecz także w poszukiwaniu nowych wzorców, w dążeniu do pełniejszej wypowiedzi. Taką właśnie strategię obok postaci kobiety - kapłanki, wieszczki (obecną w twórczości Wolskiej), prezentuje matka (w twórczości Ostrowskiej) czy ksieni, kasztelanka, święta lub kurtyzana w obrazach z przeszłości Kazimiery Zawistowskiej (por. rozdział pt. „Święte kurtyzany”. $O$ dwóch cyklach poetyckich Kazimiery Zawistowskiej). W utworach Franciszki Arnsztajnowej, w których pojawiają się motywy wykluczenia i przynależności rasowej, ważną rolę odgrywa także motyw wolnościowego zrywu, w którym kobieta może pełnić rozliczne, nowe role (por. rozdział pt. "Żotnierz i kapłanka”. O wojennych wierszach Franciszki Arnsztajnowej).

Przejście to - od konfliktu wewnętrznego, problemów „ciała w ciele”, kłopotów z płcią (Maria Komornicka), do konkret- 
nych ról społecznych, strategii lirycznych pozwala zrozumieć, jak kształtowała się sprawa kobieca w literaturze i kulturze schyłku wieku XIX. Zagadnienia emancypacji są w refleksji Mateusza Skuchy istotne, poszczególne jednak etapy kształtowania dyskursów emancypacyjnych pozostają w tle istotnych zagadnień współczesności, ujawnianych dzięki przywołaniu nowych strategii badawczych nad twórczością kobiet, w których ważną rolę odgrywają kategorie płci, seksualności. To nowe spojrzenie na kobiecość w kontekście kultury oraz jej tekstów jest ożywcze, zwłaszcza że Autor nie zapomina także o tradycji.

Jak pisał $\mathrm{w}$ cytowanym na początku eseju Baudelaire: „Dość mi, że mogę odwo- łać się do prawdziwych artystów i tych kobiet, które przyszły na świat z iskrą świętego ognia i pragną ukazać się całe skąpane w jego blasku”16 - analiza „głosów kobiecych”, „przestrzeni kobiecości”, prezentowanych w poezji portretów, pozwala zrozumieć specyfikę kobiecej twórczości, która w kulturze dwudziestowiecznej zyskała nowe, pełniejsze znaczenie.

Mateusz Skucha, Niesytość pragnienia. W kręgu młodopolskiej liryki kobiet, Wydawnictwo Uniwersytetu Jagiellońskiego, Kraków 2016, ss. 278.

16 Ch. Baudelaire, Kobieta, s. 225. 